\title{
Chloride levels increase after 13 years of recycled water use in the Salinas Valley
}

\author{
by Belinda E. Platts and Mark E. Grismer
}

The use of recycled water for agriculture is a long-term water strategy in California. A study in the 1980s in Monterey County showed recycled water increased soil salinity but not to a level unacceptable for agriculture. Most growers in the northern Salinas Valley have been using it since 1998, and yet providers of the water and many growers are concerned that the sustained use of recycled water might cause deterioration of the soil. An ongoing study, initiated in 2000, compares the changes in soil salinity between a field receiving only well water and eight fields that receive recycled water. In 13 years of data, the average soil salinity parameters at each site were highly correlated with the average water quality values of the recycled water. Soil salinity did increase, though not deleteriously. Of most concern was the accumulation of chloride at four of the sites, to levels above the critical threshold values for chloride-sensitive crops.

Tn 1987, California Agriculture described a 5-year study (from 1980 to 1985) evaluating the effects of recycled water use on soil salinity and the quality of cool-season vegetables at one location in the Salinas Valley (Engineering-Science 1987). The Monterey Wastewater Reclamation Study for Agriculture (MWRSA) concluded that soil salinity increased with the use of recycled water for irrigation, but no deleterious effects on crop production were observed. The water was delivered by the Monterey Regional Water Pollution Control Agency (MRWPCA), and the study location was in the Monterey County Water Recycling Projects (MCWRP) area.

As in all irrigated agriculture, increased soil salinity was expected (Richards 1969), and, at the end of the study, concentrations of chloride $(\mathrm{Cl})$, calcium (Ca), magnesium (Mg) and sodium

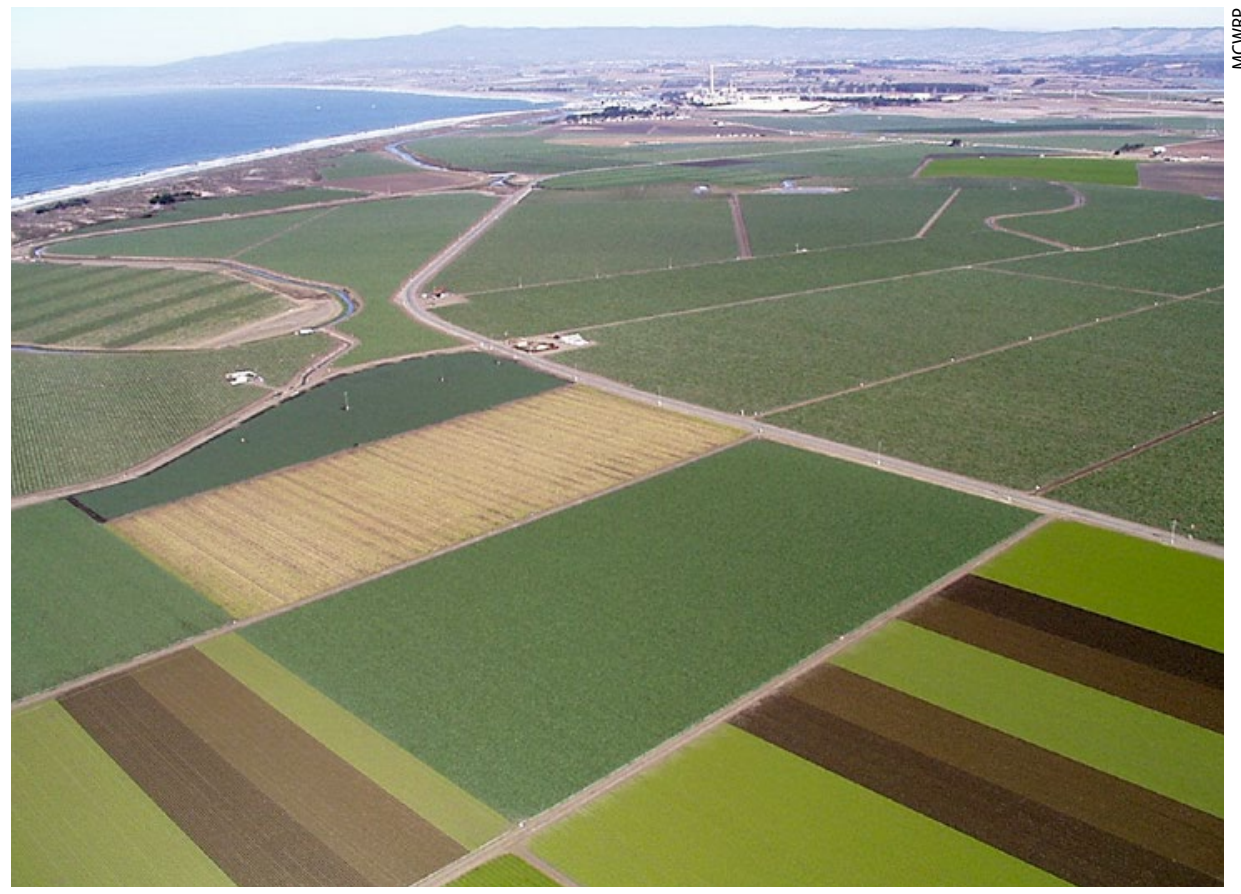

A study started in 2000 is evaluating possible long-term effects of using various levels of recycled water to irrigate Monterey County strawberry and vegetable fields.

$(\mathrm{Na})$, and the sodium adsorption ratio (SAR) were consistently higher in the soils irrigated with recycled water than in the soils irrigated with well water (Engineering-Science 1987). It was concluded that the higher values were in an acceptable range for agriculture (Oster and Rhoades 1985). Since the study found no differences in soil permeability due to the higher salinities, it appeared that longterm use would not be deleterious to the soils or require mitigation measures.

The recycled water in the MWRSA had an SAR value of 5.58, containing $8.35 \mathrm{meq} / \mathrm{L}$ (milliequivalents per liter) of $\mathrm{Na}$ and $7.03 \mathrm{meq} / \mathrm{L}$ of $\mathrm{Cl}$, and an electrical conductivity $\left(\mathrm{EC}_{\mathrm{w}}\right)$ of 1.4

TABLE 1. Optimal general agriculture and average recycled water quality values, 2000-2012

\begin{tabular}{lcc}
\hline \hline Parameter & Optimal & $\begin{array}{c}\text { Average recycled } \\
\text { water }\end{array}$ \\
\hline $\mathrm{SAR}$ & $<4.4$ & 4.94 \\
$\mathrm{Na}(\mathrm{meq} / \mathrm{L})$ & $<5.0$ & 7.64 \\
$\mathrm{Cl}(\mathrm{meq} / \mathrm{L})$ & $<7.0$ & 7.36 \\
$\mathrm{EC}_{\mathrm{w}}(\mathrm{dS} / \mathrm{m})$ & $<1.0$ & 1.62 \\
\hline
\end{tabular}

Source: Ayers and Westcot 1985.
(Engineering-Science 1987). These values were higher than what was considered optimal (table 1). Na concentrations were greater in the shallow soil profiles ( 1 to 12 inches) than in deeper soil profiles (Burau et al. 1987). In contrast, long-term salinity research indicates that soil salinity is usually greater in the deeper soil profile, because crops take up salts in the shallow soil profile, and irrigation and rainfall leach salts out of the root zone into the lower soil profiles (Rhoades et al. 1992).

In the fall of 1999, after two full seasons of irrigation with the recycled water, some growers in the MCWRP area observed significant increases in soil salinity. The Water Quality and Operations Committee of the MCWRP, a collaborative grower and agency committee, recommended that the agency evaluate the potential problem with salts. A Salt Reduction, Monitoring and Mitigation Plan for the MCWRP was developed that included a long-term soil salinity study (Sheikh et al. 2000). This ongoing study,

Online: http://californiaagriculture.ucanr.edu/ landingpage.cfm?article=ca.v068n03p68\&fulltext=yes doi: 10.3733/ca.v068n03p68 
started in 2000, is evaluating the possible long-term effects from use of varying levels of recycled water (tertiary-treated wastewater) in Monterey County on soil salinity and cool-season vegetable and strawberry production.

The soils in the study area contain relatively high levels of $\mathrm{Ca}$ and $\mathrm{Mg}$, but growers also add amendments of these elements to maintain SAR levels that ensure adequate soil permeability (infiltration) due to the high clay content of the soils. The use of recycled water with moderate salt content should not be deleterious to crop production provided there is adequate leaching of the salts out of the root zone from excess irrigation and winter rainfall. However, there is little, if any, long-term assessment of possible adverse soil impacts from recycled water use on salt-sensitive crops grown in coastal California climates.

This paper presents the data from 2000 to 2012 on factors associated with salinity, and a second paper (Platts and Grismer 2014; page 75, this issue) presents an analysis of the soil hydrology processes behind the salinity data at the test sites.

\section{Water and soil sampling, analysis}

Water sampling was conducted throughout the recycled water delivery system as a standard MCWRP monitoring procedure required by permit. For the soil salinity study, the agency added irrigation water quality tests to the monitoring program. First, the undiluted recycled water (MRWPCA's tertiary effluent) was sampled on a weekly basis to determine the levels of salt present in it before blending with the supplemental well water supplied within the distribution system to meet peak irrigation demand. Second, monthly delivery system sampling confirmed the quality of the water received by growers after dilution with supplemental well water. In addition, the quality of the well water delivered to the control site was sampled monthly. These data were used to calculate the annual average quality of water delivered to each site in the study. The water samples were analyzed for $\mathrm{pH}, \mathrm{EC}_{\mathrm{w}}, \mathrm{Na}, \mathrm{Mg}, \mathrm{Cl}$ and $\mathrm{K}$ (potassium) by an accredited laboratory run by MRWPCA.

The one control and eight test sites were randomly distributed throughout the area and were chosen based on soil characteristics, drainage systems, types of crops grown (lettuce, cole crops and strawberries), irrigation method and farming practices. The sites had Pacheco clay, clay-loam and sandy loam soils (USDA Soil Conservation Service 1978) and subsurface tile drainage systems, and had been irrigated with recycled water since 1998.
At each site, soil samples were collected from depths of 1 to 12 inches, 12 to 24 inches and 24 to 36 inches at four different locations within 3 feet of a designated global positioning system (GPS) point. Generally, two lettuce or cole crops per year are grown in the region, with plantings often in early spring and a short

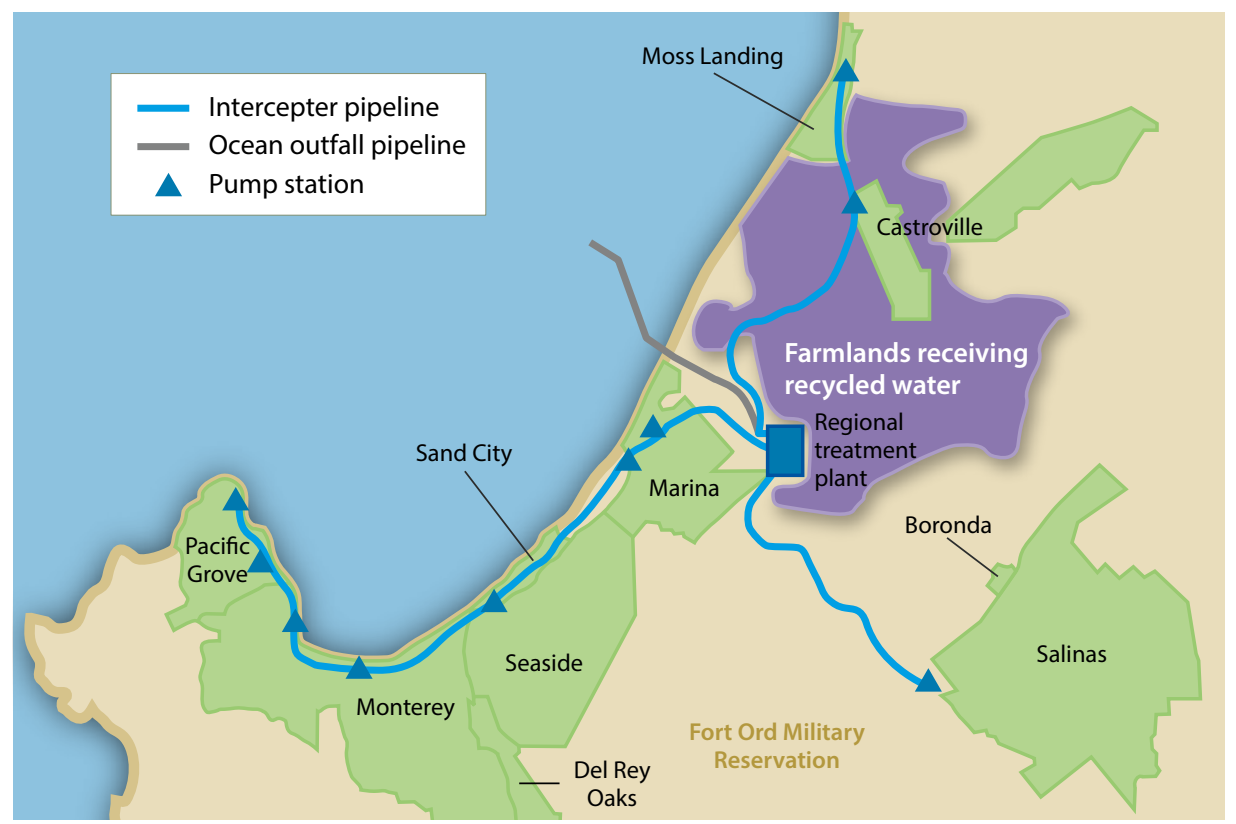

One control and eight test sites in the Monterey County Water Recycling Projects (MCWRP) area were chosen for the study. The control received only well water.

TABLE 2. Average applied water quality at treatment plant and field sites, 2000-2012

\begin{tabular}{|c|c|c|c|c|c|}
\hline Location & $\begin{array}{c}\% \text { of } \\
\text { recycled water }\end{array}$ & SAR & $\mathrm{Na}(\mathrm{meq} / \mathrm{L})$ & $\mathrm{Cl}(\mathrm{meq} / \mathrm{L})$ & $\mathrm{EC}_{\mathrm{w}}(\mathrm{dS} / \mathrm{m})$ \\
\hline WWTP* & 100 & 4.94 & 7.60 & 7.40 & 1.62 \\
\hline \multicolumn{6}{|c|}{$2000-2009+$} \\
\hline Control & 0 & 1.97 & 2.54 & 1.85 & 0.63 \\
\hline Site 1 & 69 & 3.42 & 5.27 & 5.09 & 1.13 \\
\hline Site 2 & 46 & 2.28 & 3.51 & 3.39 & 0.75 \\
\hline Site 3 & 94 & 4.62 & 7.11 & 6.88 & 1.52 \\
\hline Site 4 & 58 & 2.86 & 4.40 & 4.25 & 0.94 \\
\hline Site 5 & 93 & 4.60 & 7.09 & 6.85 & 1.51 \\
\hline Site 6 & 70 & 3.46 & 5.34 & 5.14 & 1.14 \\
\hline Site 7 & 96 & 4.73 & 7.29 & 7.05 & 1.56 \\
\hline Site 8 & 87 & 4.37 & 6.60 & 6.37 & 1.41 \\
\hline \multicolumn{6}{|c|}{ 2010-2012‡ } \\
\hline Control & 0 & 2.44 & 3.17 & 2.30 & 0.78 \\
\hline Site 2 & 92 & 3.87 & 5.81 & 5.55 & 1.12 \\
\hline Site 3 & 98 & 4.03 & 6.19 & 6.25 & 1.19 \\
\hline Site 4 & 96 & 4.13 & 6.06 & 6.35 & 1.17 \\
\hline Site 5 & 100 & 4.21 & 6.38 & 6.58 & 1.21 \\
\hline Site 6 & 90 & 3.81 & 5.71 & 5.72 & 1.09 \\
\hline Site 7 & 96 & 4.02 & 6.03 & 6.06 & 1.17 \\
\hline
\end{tabular}

* WWTP = wastewater treatment plant, average of weekly recycled water concentrations.

† Water quality based on recycled water diluted with supplemental well water.

‡ Water quality based on recycled water diluted with water diverted from Salinas River. 
parameters increased at sites 2 and 4 .

Otherwise, with the exception of site 7 , the soil salinity parameters show a fluctuation about a relatively constant value that is likely associated with the salinity of applied water.

Statistically, the whole profile (1 to 36 inches) and each subprofile (e.g., 1 to 12 inches, data not shown) means for the soil salinity parameters (EC, $\mathrm{Na}, \mathrm{Cl}$ and SAR) were significantly greater $(p<0.01)$ for the

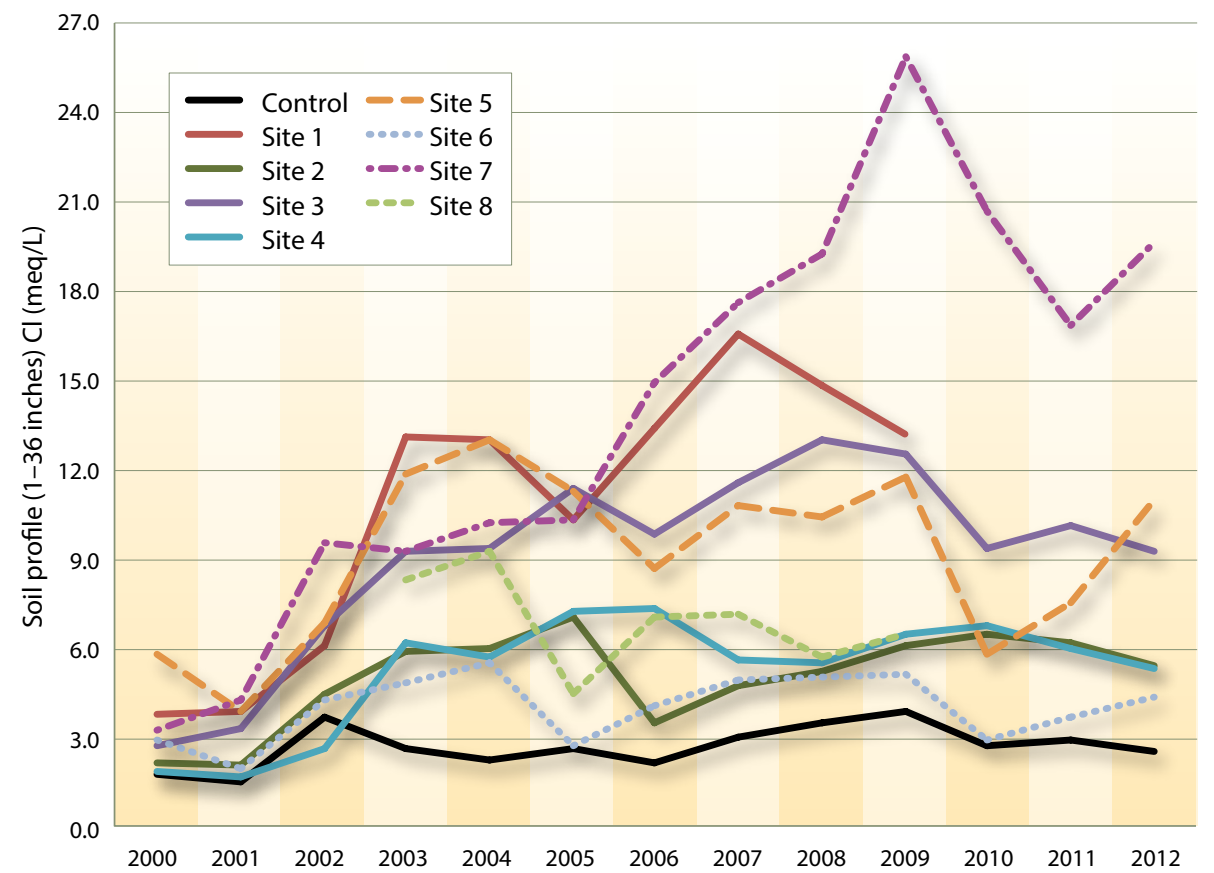

Fig. 3. Variation in soil profile $\mathrm{Cl}$ during study period.

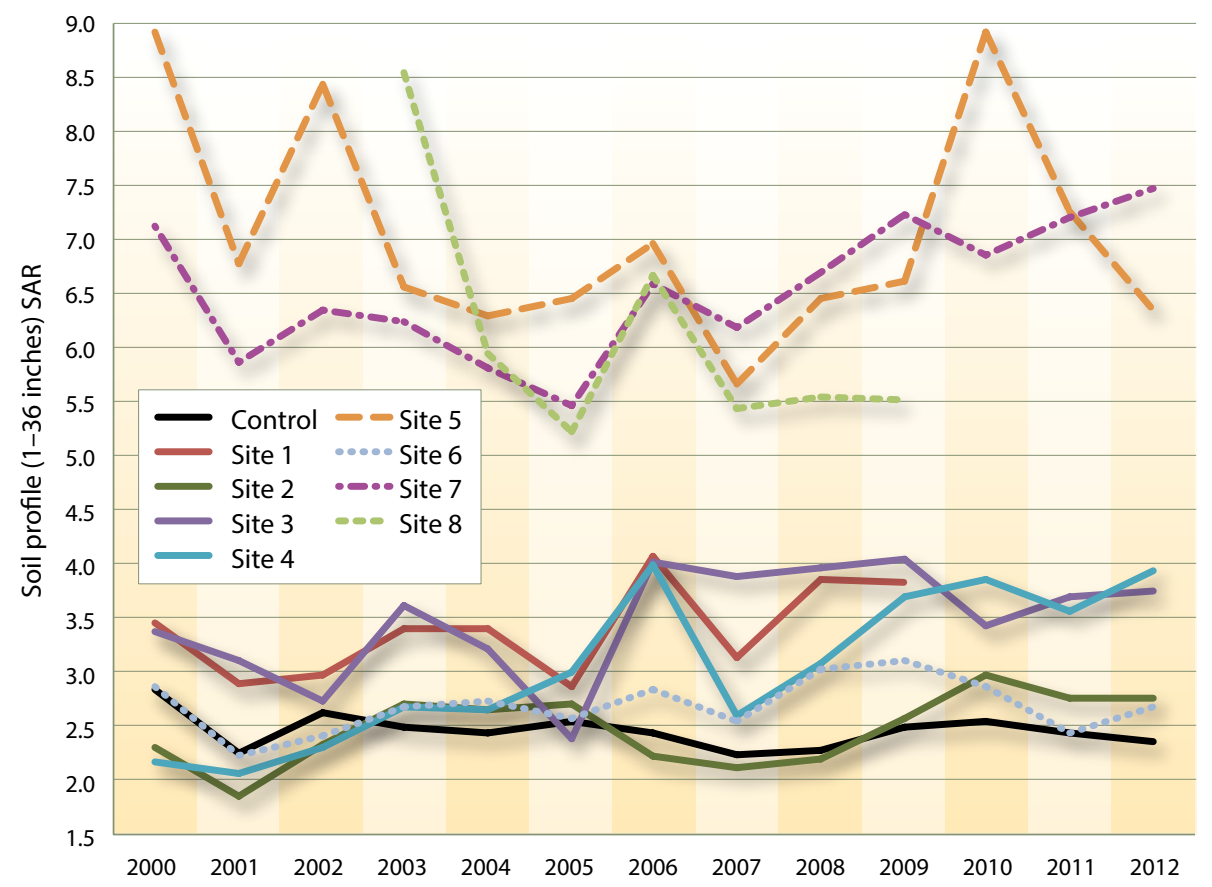

Fig. 4. Variation in soil profile SAR during study period. test sites than the control site with the exception of sites 2, 4 and 6 and the SAR values at one soil depth ( 1 to 12 inches) at site 3 . Though not significantly greater, mean soil salinity parameters at sites 2,4 and 6 were greater nonetheless. Sites 1 and 7, and to a lesser degree site 5, had larger soil EC, $\mathrm{Na}$ and $\mathrm{Cl}$ values than the other sites, which may be related to unquantified factors including irrigation water quality prior to delivery of recycled water.
Overall, soil EC, $\mathrm{Na}$ and $\mathrm{Cl}$ increased at site 7 , while only soil $\mathrm{Cl}$ accumulated at site 1 . The greatest SAR values were generally at a depth of 24 to 36 inches at all sites (data not shown), suggesting that salts were generally leaching from the root zone deeper into the soil profile. SAR values increased at site 4 following the change in the quality of the applied water. The soil $\mathrm{Ca}, \mathrm{Mg}$ and SAR values are not as well correlated with the percentage of recycled water, as these are highly influenced by grower amendment practices.

With the exception of sites 5, 7 and 8, the average site soil profile SAR values, which ranged from roughly 2 to 4 , suggest that the $\mathrm{Ca}$ and $\mathrm{Mg}$ ions balancing the $\mathrm{Na}$ ions are at satisfactory concentrations, and therefore soil infiltration problems are not anticipated at these sites. However, in the shallow root zone (1 to 12 inches) at the control site and sites 2, 4 and 6, the $\mathrm{EC}_{\mathrm{e}}$ was 1.5 to $2.0 \mathrm{dS} / \mathrm{m}$ (deciSiemens per meter; data not shown), suggesting possible yield losses with lettuce and strawberries, though this is an acceptable level for celery; while at sites 5 and 8, values of $\mathrm{EC}_{\mathrm{e}}$ between 2.5 and $3.0 \mathrm{dS} / \mathrm{m}$ remained acceptable for artichokes, broccoli, cauliflower and rapini. The $\mathrm{EC}_{\mathrm{e}}$ values of about $4 \mathrm{dS} / \mathrm{m}$ found at sites 1 and 7 are just below the threshold yield loss for less-salt-sensitive artichokes (Grieve et al. 2012). While the EC data indicates that decreases in yield are possible based on total salt load, $\mathrm{Cl}$ concentrations remained below yield loss thresholds specific to $\mathrm{Cl}$ sensitivity for all crops grown in the region at seven of the sites (excluding site 7).

Growers in the project area annually test their soils and make planting decisions based on this data. For example, a grower with fields testing above the recommended $\mathrm{Cl}$ threshold for strawberries will not plant strawberries in those fields. In addition, fields that tend to have higher salinity levels for the second vegetable planting of the season will be planted with a more-salt-tolerant vegetable crop. This soil-testing strategy has prevented any significant yield losses during the study (no significant yield losses have been reported to or observed by MRWPCA during the study). In addition, actual yields are highly influenced by market conditions, which were quite variable during the study period; poor market prices result in the growers leaving a 
certain amount of product unharvested in the field.

\section{Statistical analysis}

A key agronomic concern is the relationship between applied water salinity, the resulting soil salinity and its potential adverse impacts on crop yields. Figures 1 to 4 clearly demonstrate the variability of soil salinity between sites and over time. In contrast, figures 5 to 8 illustrate the dependence of average soil salinity parameters regardless of site on applied water salinity parameters during the periods 2000 to 2009 and 2010 to 2012.

As anticipated, increased applied water $\mathrm{EC}_{\mathrm{w}}$ resulted in greater soil EC, particularly in the shallow (1 to 12 inches) portion of the soil profile. While the individual depth interval linear regression slopes did not differ significantly, the soil profile $\mathrm{EC}_{\mathrm{e}}$ was significantly correlated with the applied water EC, and the slope shown in figure 5 was significant $(\mathrm{CL}=$ confidence level). The linear regression slope indicates that the root zone soil EC averages were about twice those of the applied water $\mathrm{EC}_{\mathrm{w}}$. However, the shallow soil (1 to 12 inches) EC was only about 7\% greater than that deeper in the soil profile (12 to 36 inches).

Compared with EC, soil $\mathrm{Na}, \mathrm{Cl}$ and SAR values showed much less

\section{A key agronomic concern is the relationship between applied water salinity, the resulting soil salinity and its potential adverse impacts on crop yields.}

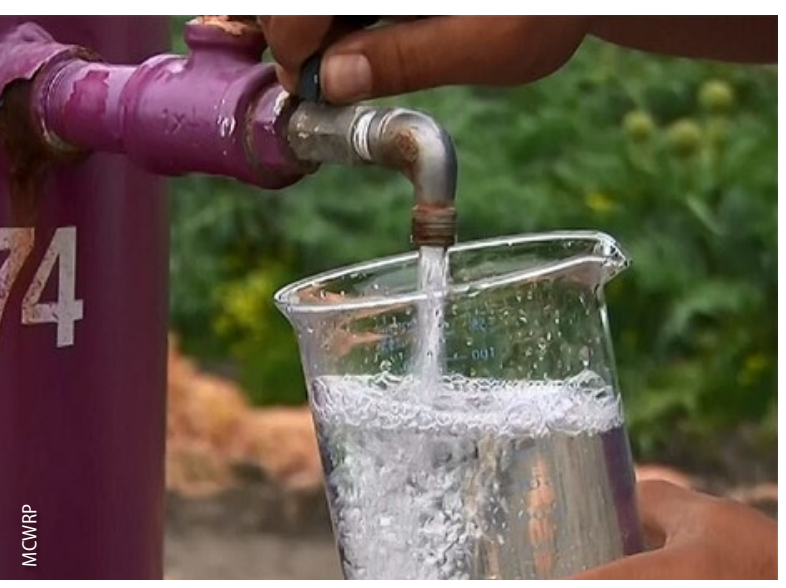

Recycled water was sampled at the treatment plant and at delivery to growers' fields. dependence on applied water values up to thresholds of approximately $5.5 \mathrm{meq} / \mathrm{L}$ for $\mathrm{Na}$ (fig. 6) and $\mathrm{Cl}$ (fig. 7) and about 4 for SAR (fig. 8). At applied water values greater than these, soil $\mathrm{Na}, \mathrm{Cl}$ and SAR values increased dramatically, though with considerable variability. When applied water values for $\mathrm{Na}, \mathrm{Cl}$ and $\mathrm{SAR}$ were below the thresholds, soil values were equivalent to the values of the applied water, suggesting the applied water was leaching through the profile. Leaching of $\mathrm{Na}$ deeper into the soil is evident from the increasing linear regression slopes (not shown), with soil Na ranging from approximately four times that of the applied water $\mathrm{Na}$ at 1 to 12 inches, to five times at 12 to 24 inches and more than

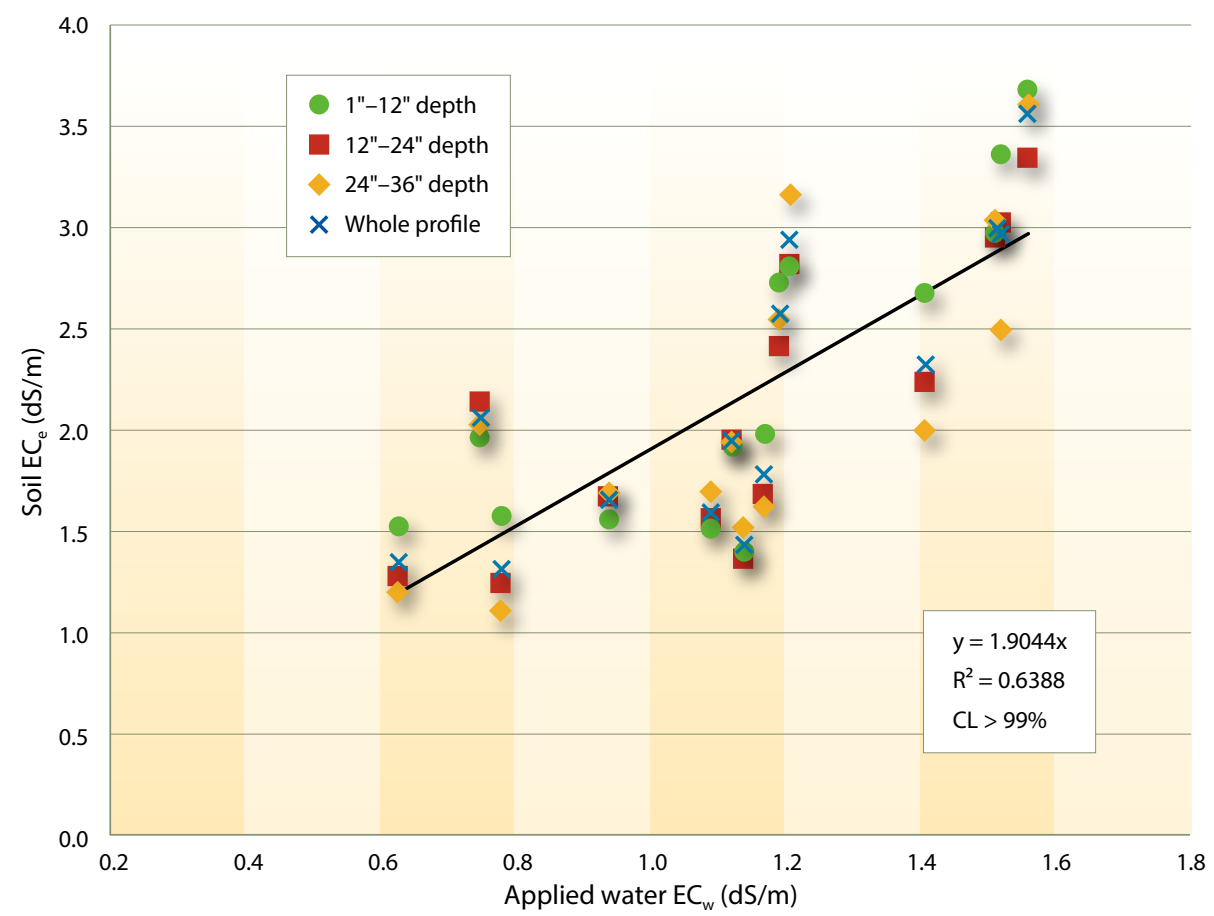

Fig. 5. Dependence of soil $\mathrm{EC}_{\mathrm{e}}$ on applied water $\mathrm{EC}_{\mathrm{w}}$ during study period.

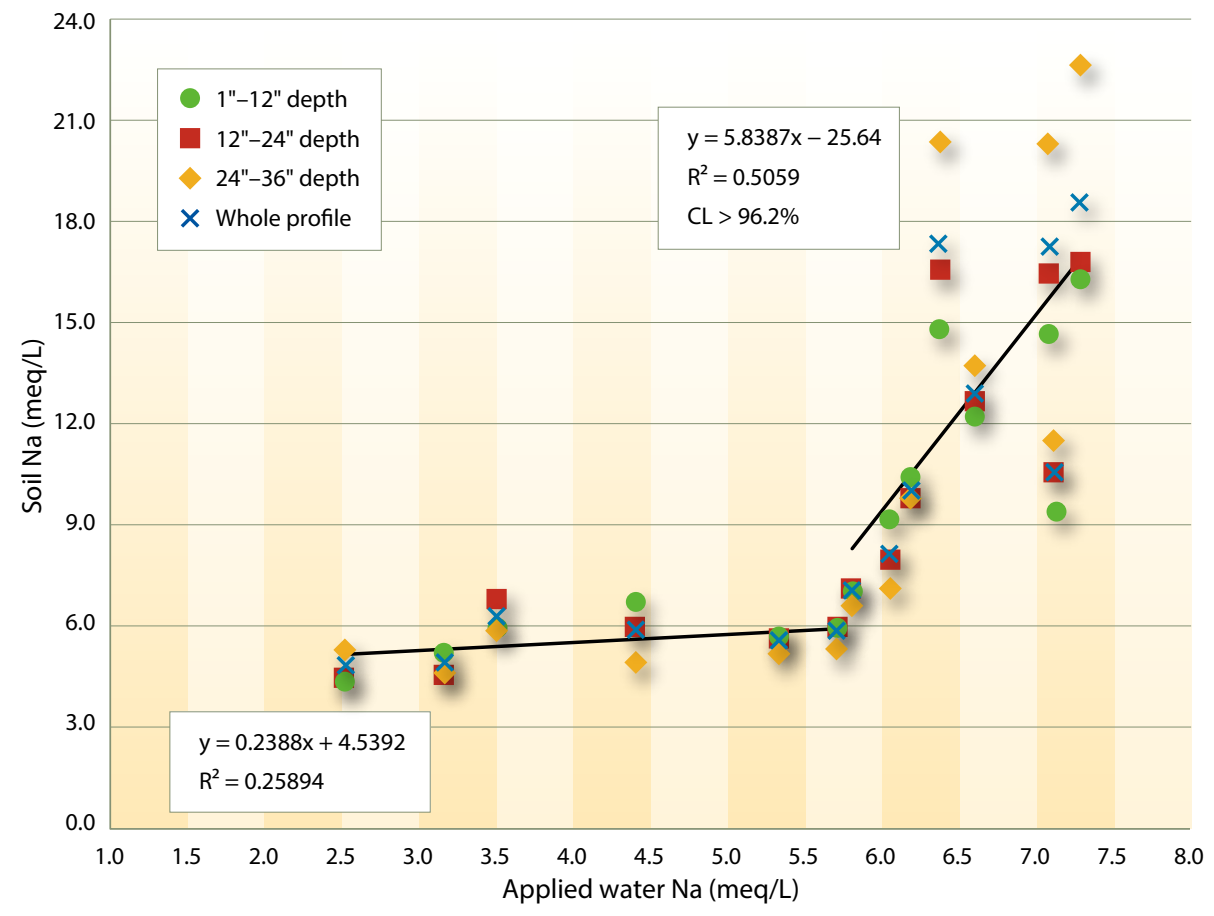

Fig. 6. Dependence of soil Na on applied water Na during study period. 
eight times at 24 to 36 inches, and averaging nearly six times for the soil profile as a whole.

Not surprisingly, the dependence of soil $\mathrm{Cl}$ on applied water $\mathrm{Cl}$ shows a similar relationship to that of $\mathrm{Na}$ (fig. 7 ), though the increases in soil $\mathrm{Cl}$ at applied water values greater than about 5.5 meq/L across the soil subprofiles are less than those for $\mathrm{Na}$. This likely reflects the greater mobility of $\mathrm{Cl}$ in the soil compared to Na. It is of major concern that at applied water $\mathrm{Cl}$ values more than 5.5 meq/L, soil Cl concentrations increased across all depths.

Soil SAR values roughly match those of the applied water SAR values up to about 4, after which soil SAR values are about 1.5 times greater than the values of the applied water, though the correlation of soil SAR and applied water SAR was less than significant (CL < 95\%).

These results indicate that the effect of the quality of applied water on soil salinity is dependent on the level of salts present in the applied water. It is important to note that there may be other factors responsible for the variation in soil salinity parameter values, including growers' use of soil amendments, and the combined effects of applied water and winter rainfall leaching must be considered. A second paper in this issue contains an analysis of the data from the perspective of soil water balance and addresses these effects (Platts and Grismer 2014, page 75).

\section{Accumulation of chloride}

As competition for water supplies intensifies and associated sea water intrusion affects the use of well water in coastal California areas, the long-term effects on soil salinity from use of recycled water are important to investigate. Our primary objective was to quantify the changes in salinity in Monterey County fields under intensive production and determine whether the long-term use of recycled water there has been deleterious to the types of soils in the area.

Our analysis of study data from 2000 to 2012 supports the general conclusions of the MWRSA in the 1980s: The use of recycled water has caused an increase in soil salinity in the area; however, SAR values are not deleterious and $\mathrm{Na}$ has shown little accumulation in the rooting zone (1 to 12 inches).

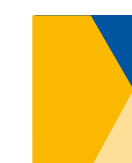

\section{Can irrigation with municipal wastewater conserve energy?}

Water conservation and energy costs were concerns 35 years ago, just as they are today. This study looked at whether reuse of wastewater on farmland would require less energy than discharging it to the ocean. If so, would it require more or less energy than importing fresh water for irrigation? In 1977, the energy costs came out about even. Would today's energy costs and irrigation/wastewater technologies yield a different result?

1977 "Approximately 80 percent of the potential for reclamation in California is in basins where wastewater is being discharged to brackish or saline water - mainly the Pacific Ocean.

"One of the expected benefits of wastewater reuse is energy savings in those situations where reuse is an alternative to importation of fresh water.... Two important questions, then, are: (1) Would reuse of wastewater on farmland require less energy than discharge to the ocean? (2) If so, would it require more or less energy than importation of fresh water for irrigation?

"Municipal wastewater discharged to the Pacific Ocean requires considerable energy for secondary treatment (biological oxidation and assimilation of organic matter) and pumping through a long ocean outfall. Since wastewater reused for irrigation of fodder, fiber, and seed crops requires only primary treatment (screening and settling processes), each acre-foot reused could save about $200 \mathrm{KWH}$ in direct energy requirements - compared to ocean disposal - by eliminating the secondary treatment and ocean outfall pumping.

"Under current health regulations wastewater reused for pasture irrigation and surface irrigation of food crops requires secondary treatment. Therefore reuse instead of ocean disposal would save only the approximately $50 \mathrm{KWH}$ otherwise required for outfall pumping. Wastewater reused for sprinkler irrigation of food crops requires secondary treatment plus chemical coagulation and filtration. Such reuse would require slightly more direct energy — possibly $10 \mathrm{KWH} / \mathrm{AF}$ — than ocean disposal of the wastewater.

"When only these direct energy requirements are considered, it appears that irrigation with wastewater could save very large amounts of energy compared with importing fresh water. However, elevation and quality differences tend to offset the benefits."

Roberts EB, Hagan RM. 1977. Energy: Can irrigation with municipal wastewater conserve energy? Calif Agr 31(5):45.

Robert Hagan served the UC Davis community as professor of water science from 1948 until his retirement in 1987. In addition to his expertise on agricultural water use under arid conditions, Hagan sought to increase constructive communication between growers and environmental groups on issues of water and resource use. The UC Davis Robert M. Hagan Endowed Chair in Water Management and Policy was established in his honor.

Co-author Edwin B. Roberts served as a staff research associate at UC Davis, working with Professor Hagan.

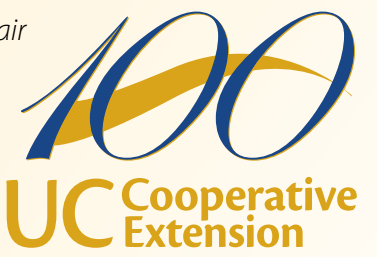
-W. J. Coats 
Although MRWPCA has worked to reduce the levels of $\mathrm{Na}$ and $\mathrm{Cl}$ in the water delivered to growers, there has been accumulation of $\mathrm{Cl}$ and increased $\mathrm{EC}_{\mathrm{e}}$ values in the soil profile that were not documented during the earlier study. It appears that winter rainfall has been inadequate to leach out the $\mathrm{Cl}$ and reduce $\mathrm{EC}_{\mathrm{e}}$. This accumulation of $\mathrm{Cl}$ needs to be mitigated in order for growers to continue producing high yields of chloridesensitive crops such as strawberries and leafy greens. Mitigation options include eliminating amendments that contain $\mathrm{Cl}$, increasing the leaching fraction and improving drainage. Given that using recycled water is an important water strategy in California, further research

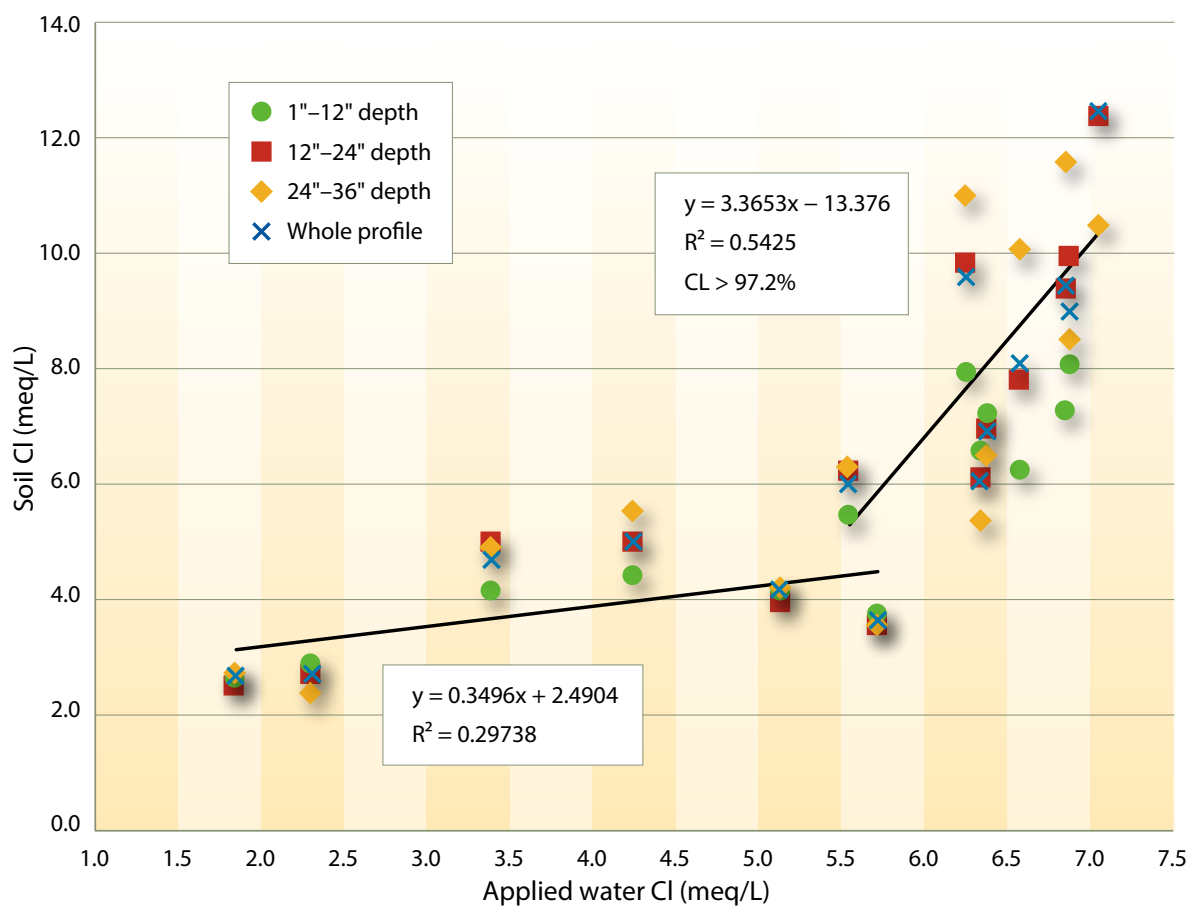

Fig. 7. Dependence of soil $\mathrm{Cl}$ on applied water $\mathrm{Cl}$ during study period.

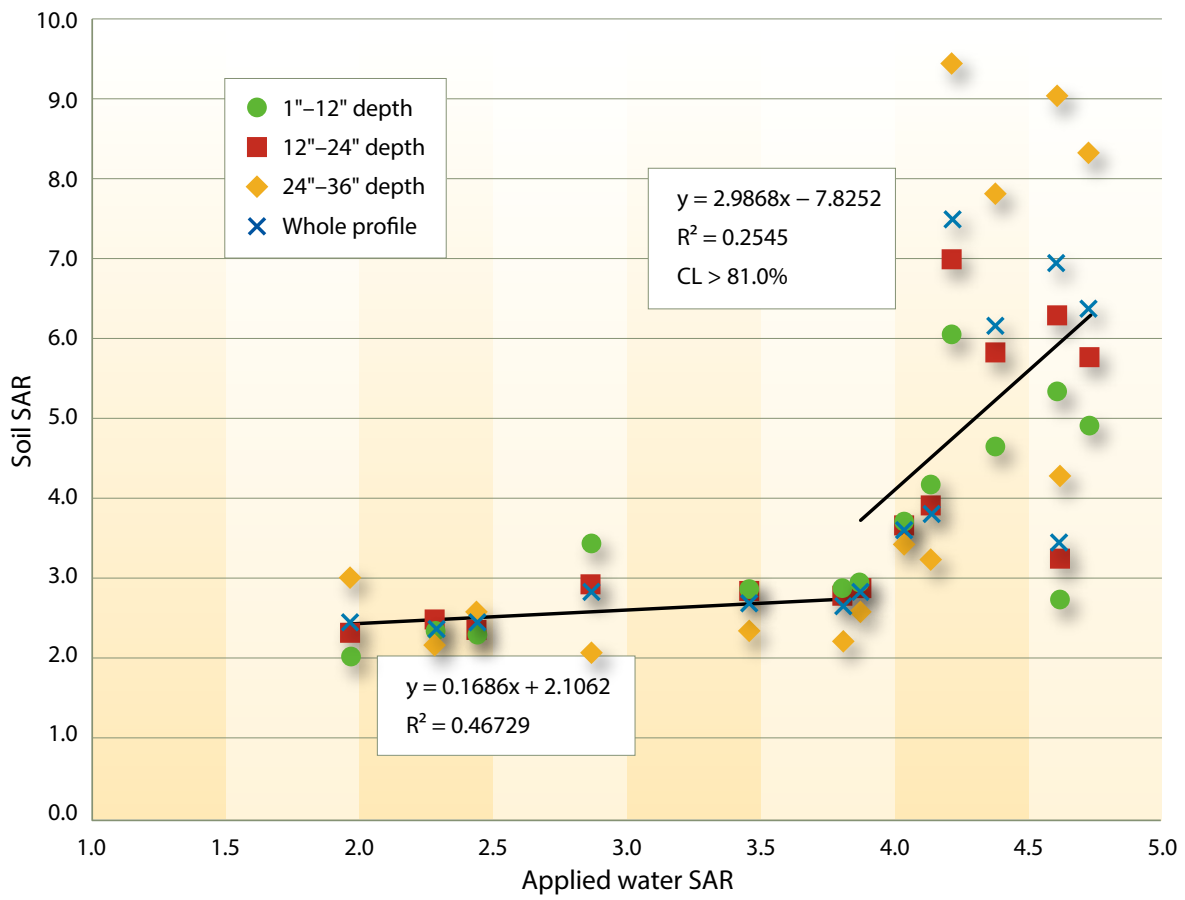

Fig. 8. Dependence of soil SAR on applied water SAR during study period.

may be needed to determine the cause of the $\mathrm{Cl}$ accumulation and to develop effective mitigation strategies when recycled water is used to grow chloride- and saltsensitive crops.

B.E. Platts is Agricultural Consultant, Monterey Regional Water Pollution Control Agency (MRWPCA); and M.E. Grismer is Professor of Hydrologic Science and Biological and Agricultural Engineering, Department of Land, Air and Water Resources, UC Davis.

Monterey County Water Resources Agency (MCWRA) has voluntarily funded the research. We acknowledge the support of MRWPCA personnel and growers within the MCWRP area. William Franks and Jesse Chacon of MRWPCA diligently collected the soil and water samples every year. Patrice Parsons and Bob Holden of MRWPCA have been instrumental in providing water quality data and reviewing the data annually. The grower representatives on the Water Quality and Operations Committee have provided the sampling sites and a high level of interest in this research.

California Agriculture thanks Guest Associate Editor Stephen R. Grattan for his work on this article.

\section{References}

Ayers RS, Westcot DW. 1985. Water Quality for Agriculture. FAO Irrigation and Drainage Paper 29. Rome: Food and Agriculture Organization of the United Nations.

Burau RG, Sheikh B, Cort RP, et al. 1987. Reclaimed water for irrigation of vegetables eaten raw. Calif Agr 41(7):4-7.

Engineering-Science. 1987. Monterey Wastewater Reclamation Study for Agriculture (MWRSA). Final report. Berkeley, CA.

Grieve CM, Grattan SR, Maas EV. 2012. Plant salt tolerance. In: Wallender WW, Tanji KK (eds.). Agricultural Salinity Assessment and Management. ASCE Manuals and Reports on Engineering Practice No. 71 (2nd ed.). Reston, VA: American Society of Civil Engineers (ASCE). p 405-59.

Oster JD, Rhoades JD. 1985. Water management for salinity and sodicity control. In: Pettygrove GS, Asano T (eds.). Irrigation with Reclaimed Municipal Wastewater - A Guidance Manual. Chelsea, MI: Lewis Publishers

Platts BE, Grismer ME. 2014. Rainfall leaching is critical for long-term use of recycled water in the Salinas Valley. Calif Agr 68(3):75-81 (this issue).

Rhoades JD, Kandiah A, Mashali AM. 1992. The Use of Saline Waters for Crop Production. FAO Irrigation and Drainage Paper 48. Rome: Food and Agriculture Organization of the United Nations.

Richards LA (ed.). 1969. Diagnosis and Improvement of Saline and Alkali Soils. Agriculture Handbook No. 60. Washington: USDA, US Government Printing Office.

Sheikh B, Platts B, Holden B. 2000. Salt Reduction, Monitoring and Mitigation Plan for Monterey County Water Recycling Projects. Approved by Water Quality and Operations Committee, July 27, 2000. Monterey, CA: Monterey Regional Water Pollution Control Agency.

USDA Soil Conservation Service. 1978. Soil Survey of Monterey County, California. Washington: USDA. www.nrcs.usda.gov/Internet/FSE MANUSCRIPTS/ california/CA053/0/monterey.pdf. 